AUTHOR:

Steve Bishop (10)

https://orcid.org/0000-0002-4547-0597

AFFILIATION:

City of Bristol College

CORRESPONDENCE TO:

stevebishop.uk@gmail.com

DATES:

Published: 7 December 2020

HOW TO CITE THIS ARTICLE:

Bishop, S., 2020. Kuyperania 2019.

KOERS - Bulletin for Christian

Scholarship, 85(1). Available at: https://

doi.org/10.19108/KOERS.85.1.2476

COPYRIGHT:

(c) 2020. The Author(s)

Published under the Creative

Commons Attribution License.

\section{Kuyperania in 2019}

\author{
ABSTRACT \\ This article looks at new works published in 2019 by or about the Dutch polymath Abraham \\ Kuyper. \\ KEY CONCEPTS: Abraham Kuyper, Christ's kingship, Common grace, education, international \\ relations
}

\section{ABSTRAK}

Hierdie artikel kyk na nuwe werk gepubliseer in 2019 deur of oor die Nederlandse polimaat Abraham Kuyper.

KERNBEGRIPPE: Abraham Kuyper, Christus se koningskap, gemeenskaplike genade, opvoeding, internasionale betrekkinge

\section{INTRODUCTION}

B.B. Warfield, it is alleged, learnt Dutch so he could read Kuyper. Fortunately, English monoglots no longer have to do so, thanks to the efforts of the Abraham Kuyper Translation Project. Three large, beautifully produced, volumes were published in 2019. It is these I will examine first.

\section{TRANSLATIONS OF KUYPER}

\subsection{Common Grace volume 2}

The details in the style of Kuipers (2011) of this translation are as follows.

\author{
01 Common Grace \\ God's Gift for a Fallen World Volume 2 \\ The Doctrinal Section \\ Bellingham, WA, Lexham Press 2019. 600 pp., 18.8 x 6.1 x 25.9 cm, - £31.65/ \\ $\$ 49.99$ \\ Translation of: 1903.13 De Genentech Gracie. Tweede deel. Het leerstellig \\ gedeelte. \\ Translator: Nelson D. Kloosterman and Ed M. van der Maas \\ Edited by Jordan J. Ballor and J. Daryl Charles \\ Introduction by Craig Bartholomew \\ Binding: Hardback \\ Published: April 2019 \\ ISBN 9781577996699
}

A key question Kuyper poses at the start of this second volume is: 'Why does the world turn out to be better than expected and the church worse than expected?' (see, for example, Kuyper 2019a:10, 19, 29, 30). The answer Kuyper proposes, unsurprisingly, given the topic of this book, is common grace. As in the previous volume, Kuyper maintains a sharp 
distinction between common and particular grace. The main function of common grace is 'temporarily mitigating and restraining human self-destruction' (2019a:24). However, there is an intimate link between the two:

... particular grace presupposes common grace, and .. common grace is the broad pedestal on which particular grace is erected (2019a:109).

And

... particular grace cannot exist apart from common grace for even a moment (2019a:777).

Kuyper situates common grace in predestination:

Only what has its roots in predestination can find its rightful place in the dogma of the church and in the theologians study (2019a:112).

He notes that failing to do this has, in some measure, resulted in the neglect of common grace:

Virtually the only thing that was seen in predestination was particular grace that concerned the elect and the lost, and consequently common grace wandered outside the gate, unable to find a place of its own (2019a:112).

To remedy this he first presents a 'more general discussion of the nature of predestination' (2019a:113). He questions the view that predestination is exclusively concerned with the fate of the individual. This limiting view of predestination, Kuyper argues, predated Reformers such as Johannes à Marck (1656-1731) and Wilhelmus à Brakel (1635-1711). Kuyper identifies it in Aquinas, though Aquinas's view of regeneration is very different from a Reformed view.

It is against this one-sided and limited notion of the decree of predestination that we must lodge our protest, not least in the name of holy Scripture itself. For in this way we isolate humanity from the rest of creation (2019a:119).

Only when we take "all things" together do we have the whole work of God before us. God did not create angels and humans and in addition all kinds of superfluous things. In God's creation nothing is secondary, nothing is superfluous, nothing can be dispensed with (2019a:123).

Kuyper then looks at the connection between common grace and Christology. He asserts that the administration of justice is seen as common grace in action (cf. Ch 21).

The time when Jesus came is attributed to common grace-but this could also be seen as God's providence. There is much overlap between the providence of God and common grace; indeed some have insisted that common grace can be explained in terms of God's providence (see, for example, Brummel, 2018). Kuyper explores the links between the two.

Providence flows from God's decrees and common grace is determined by God's providential plan (Kuyper, 2019a: ch. 3). Both operate outside of saving grace; however, as he rightly points out, belief in providence outside of saving faith is closer to deism than Christianity. He thus laments that among believers there is not a 'clear discerning insight into the essence of the doctrine of providence'. The ideas seem to be more pagan than biblical. He warns:

We must seriously guard against the danger of adopting pagan notions and then mixing them with the content of revelation (2019a:417). 
He goes on:

The task before us is precisely the opposite to analyse the content of Scripture as clearly as possible in constructing doctrine, and through this analytical process to exclude all that is unchristian and foreign (2019a:417).

Providence is not a determination of what will happen, but rather the execution of what has already been decreed. It is the maintenance and governance of all things, not a pagan notion of seeing ahead (pro vide). A proper understanding of the providence of God is

...the confession that the counsel and decrees of God are all-embracing, that the eternal counsel of God encompasses all things, and that nothing can be named or imagined - regardless of how large or small — that is not included in and does not proceed from the decrees of God (2019a: 420).

He warns against two extremes associated with wrong notions of providence. A deistic framework where creation and providence take up two separate identities, so that we become independent of God. If creation has an independent existence it leads to atheism via Pelagianism and deism. On the other hand, if the distinction between them is dissolved it leads to panentheism. Our independent existence becomes an illusion. This is false mysticism. God is absorbed into the being of the world. A biblical perspective holds to the truth of an independent existence of things outside the being of God and that this independent existence is possible only because it rests in the will and power of God.

Providence, Kuyper is very clear, is not to be seen as a continuing creation. Creation causes things to 'come into existence outside of God' whereas providence entails existing things to exist and develop. Providence, therefore, is not a supplemental creation. The corollary of this is that miracles are not to be viewed as a second creation.

Providence depends on common grace, without common grace, ‘no providential ordination if God would be manifest at all.' But also common grace 'is encompassed entirely by God's providential order and hence arises from it'.

Kuyper also examines the relationship of God and suffering. Much suffering also has its origin in the curse, the curse was the result of God's ordination, yet we can also see the working of Satan in it. Thus some suffering comes on the one hand as God's will and yet on the other 'as something against which his compassion does battle'.

Kuyper is clear:

The Christian duty not only to combat suffering that has come upon us but also, where possible, to avert through precautionary measures the suffering that could come upon us ...we must fight against all suffering, and suffering that can be prevented must be averted by precautionary measures (2019a:598).

Which leads Kuyper on, in chapters 62-63, to discuss vaccinations (on this see Bishop 2019b). In the 1870s there were some vehement objections against the use of it. Many thought the imposition of compulsory vaccinations was a denial of civil liberties and many also thought it was ineffective. In The Netherlands the debate also took on religious overtones. These views Kuyper suggests were based on misguided and errant piety. He advocated vaccinations but disagreed that the government should make them compulsory, as this was an overreach of the government.

Kuyper concludes volume 2 by re-examining the relationship between particular and common grace, once again reiterating that particular grace enriches common grace and common grace is presupposed by particular grace. 
He makes it clear that preparation for heaven is not the ultimate goal of life on earth, but rather it is the glorification of God's name. We are therefore not to withdraw from the world, because we are to bear witness to the world, and to manifest the power of kingdom in the life of the world. In this the working together of particular and common grace is required:

And indeed the working of the one can never reach its ultimate goal without the working of the other (2019a:749).

Another volume published in 2019 by the Abraham Translation Project is the third and final volume of Pro Rege.

\subsection{Pro Rege Volume 3}

The details in the style of Kuipers (2011) of this translation are as follows.

02 Pro Rege

The Kingship of Christ Volume 3

The Kingship of Christ in its Operation

Bellingham, WA, Lexham Press 2019. 482 pp., 18.8 × 6.1 × 25.9 cm, - £31.65/\$49.99

Translation of: 1912.01 Pro Rege of net Koningschap van Christus. Derde deel. Het Koningschap van Christus in zijn werking.

Translator: Albert Gootjes

Edited by John Kok and Nelson D. Kloosterman

Introduction by Rimmer de Vries and Jordan J. Ballor

Binding: Hardback

Published: July 2019

ISBN 9781683593126

This, the final translated volume of Pro Rege, has four main sections:

Christ's kingship and society

Christ's kingship and the state

Christ's kingship and knowledge

Christ's kingship and art

The previous volume ended with chapters on the family, here before examining the state, Kuyper looks at society. He identifies four independent factors in human life: family, society, the state and church.

Social life forms a terrain of its own, and is too a terrain that Christ enters with his kingly majesty in order to rule it (2019b:6).

In this section he discusses topics as diverse as money, play and women. His views on women show how much he was a person of his time. They display patronising, stereotypical views on women assuming their main role is in the home.

As ever, Kuyper sees the lordship of Christ as comprehensive:

Christ's kingship extends over all things, extends to every part of human life, also in society. Only when we recognize and honour the fact that Christ's kingly dominion extends also over society can we stand strong in it (2019b:6). 
In the second section Kuyper discusses the state. He sees the state as being the consequence of the fall:

... the state never would have existed had the fall into sin never occurred; that in the state we only have an aid to counter the consequences of sin; that the state will accordingly exist only for so long as sin continues to roil about; and that in the kingdom of heaven there will no longer be any division into states, so that the human race might once more be revealed as a unity (2019b:190).

This view is an Augustinian view and one has not accepted by all Kuyperians, many would see the state and government as part of creation (see, for example, the discussion in Min 2009: ch 2).

Looking back from the present to the past, people are easily inclined to imagine that the state has always existed This is not, however, how it was, nor could it have been; and according to Scripture, this is also not how things were (2019b:189).

The genesis of the state he places at Babel. This marked the division into of a united human race into separate parts. These separate parts were later, when populations increased, to develop into states (194). Patriarchy gave way to kingship and thus established a state (202). The characteristics of a state he sees as being one land, one people, one law, one leader, one language, and be independent of every other earthly power (204).

Kuyper sees the role of the state as being a consequence of common grace:

That the unity of the world be expressed in a plurality of independent states was sought by God and fostered and realized through common grace. In its sinful condition the world was no longer able to master its own future as a powerful unity If higher development of human life was to prove possible, division and separation were indispensable; and only the formation of states could provide the separated groups with the bond and stability they needed for achieving a higher form of human life (2019b:206).

He notes that it wasn't until recently, until the French Revolution that an attempt was made to spurn common grace (2019b:204).

Part three deals with knowledge. He distinguishes between immediate knowledge and experiential knowledge. Kuyper begins by comparing and contrasting humans' immediate knowledge with Jesus'. He rejects the idea that Jesus' knowledge displayed in the Gospels is because of his omniscience, rather it is evidence that humans have lost or dimmed some forms of knowledge such as intuition, tact and wisdom. He briefly discusses some unusual forms of knowledge such as presentiments, clairvoyance and hypnotism, while recognising these can be demonic illusions seems to suggest that they can be real forms of knowledge.

He then moves on to discuss science and Science. As regards the latter he remarks:

As Science this power presents itself as a queen who considers the entire existing world to be her domain In fact, not infrequently Science is presented as an oracle, a goddess by whom all human beings are expected to swear And with the cry "Great is Artemis of the Ephesians!" [Acts 19:28], the fame of this goddess of knowledge is spreading ever more widely (2019b:310).

He provides a profound discussion of the idolatry of Science. Typical of his comments is this:

Whatever the dispute may be, Science is expected to resolve the matter And more telling yet is that Science, and Science alone, is held to be what sets the tone for all 
our thinking, and for our entire life- and worldview That is why Science ultimately had to end up where it did, attempting to wrest the crown from Christ (2019b:310311).

In the final section, Kuyper looks at art in its 'entirety'. He stresses that art is not merely a human fabrication but is a 'function of the human mind that God himself placed in our lives' (383). It 'cannot be anything but a gift of God' (383). Here he develops the notion that art is a gift of God that shows itself in an ability, which portrays beauty and can be enjoyed by all.

\subsection{On Education}

03 On Education

Bellingham, WA, Lexham Press 2019. 352pp., 17.8 × 25.4 cm, - £42.99/ \$44.99

Translation of: Numerous of Kuyper's parliamentary speeches and newspaper articles.

Translator: Harry Van Dyke

Edited by Wendy Naylor and Harry Van Dyke

Introduction Charles L. Glenn

Binding: Hardback

Published: December 2019

ISBN 9781577996774

This volume opens with a bold key statement from the editors:

Abraham Kuyper, accomplished much over the course of his lifetime, but perhaps his most lasting contribution to Dutch society was a radical restructuring of the Dutch school system according to the principle of religious liberty (Naylor, in Kuyper 2019c:xi).

This volume provides much evidence for the veracity of that statement.

The school struggle as it became known was the fight for parents, and not the state, to control the education of their own children. Kuyper's Anti-Revolutionary Party's policy was that 'the government should not be operating schools as a rule but only by way of exception' (Kuyper, 2019c:45). It was a decades long struggle and one that Kuyper soon realised was to require political change.

The introduction by Naylor, provide the historical and cultural context of Kuyper's time and examines some mountains Kuyper faced in attempting to reform the school system. As Naylor notes Kuyper's programme involved a 'multifaceted rationale' (xiv) for his pluralistic educational programme.

Kuyper's multifaceted rationale for a pluralistic approach consisted in freedom of conscience, the role of core beliefs, taking education out of politics, the unity of the child, sound pedagogy, parental rights, church rights, preparation for future service to society, free initiative and civil society, justice for the poor, national unity, and Dutch culture and heritage. All these are ably discussed in the introduction. Naylor concludes by looking at the North American situation and sees taking place a similar scenario to that of the Dutch struggle.

On Education primarily contains writings that deal with the practical issues of the school struggle rather than Kuyper's educational philosophy. Kuyper draws on the key emphases in his philosophy, most notably on sphere sovereignty. As this quote illustrates: 
The school should belong, not to the church, not to the state, but to parents (2019c:198).

One key argument that persisted was the distinction between subsidy and restitution. Kuyper argued that restitution was required for parents who set up private schools rather than a subsidy. This was because restitution implies a refund to the private schools of the expenses that saved the state rather a hand out. Or as Kuyper put it:

Why are we so opposed to subsidies? Why do we despise them with all our might? The reason is obvious. A subsidy is an arbitrary allowance given by the rich to the poor, depending on his whim and caprice (2019c:249).

Kuyper argued, convincingly, that the private schools meant that the parents had saved a great deal of money, because it meant the state had fewer schools to fund. His arguments or reasons for private education that are scattered through this anthology include (in no particular order) the following.

- The harmony between home and school will be much stronger than in a state school

- They produce results at least as good as the state schools-without the state schools 'Kantian deism and its doctrine of moral autonomy' (262)

- Child rearing and thus education is the role of the parents and not the state-it should be an issue of parental choice

- It is an issue of equality: 'There must be equality in the country, both for those who hold to the Christian and for those who hold to the modernist worldview' (286).

- Education is not neutral, state education flattens and demeans religious faith: 'There is no neutral education that is not governed by a spirit of its own. And precisely that spirit of the religiously neutral school militates against every positive faith' (290).

- $\quad$ All teachers and educationalists operate from a set of theoretical and pre-theoretical frameworks; neutrality is impossible.

- The need for diversity in education to represent the different cultural and religious worldview within The Netherlands.

State education and the arguments for it are, Kuyper insists, products of moral autonomy, and thus a rejection of the sovereignty of God; it was a deification of the state, and although he does not put in in these terms it involved state indoctrination.

The editors have done well to sift through the mountain of writings and speeches Kuyper produced on education to produce such an excellent overview of Kuyper's approach to education and the school issue.

\section{BOOKS ON KUYPER}

\subsection{Engaging the World with Abraham Kuyper (Lived Theology)}

This superb book by Mike Wagenman is a mix of biography and exposition of Kuyper's life and work. Wagenman, whose PhD is soon to be published by Wipf and Stock, examines six areas of Kuyper's teaching: identity, public discourse, education, the church, society, and politics. As well as looking at these areas, he identifies how they can apply to society today. This is perhaps the best introduction to Kuyper available - the one weakness is that it fails to do justice to Kuyper's view of common grace. 


\subsection{Article 36 of the Belgic Confession Vindicated against Dr Abraham Kuyper}

This book, recently translated by Ruben Alvarado, a contemporary of Kuyper's, takes Kuyper to task over his disagreement with Article 36 of the Belgic Confession. Article 36 has been controversial for several reasons. It looks at the role of the magistrates and the church. The most controversial section reads:

And the government's task is not limited to caring for and watching over the public domain but extends also to upholding the sacred ministry, with a view to removing and destroying all idolatry and false worship of the Antichrist; to promoting the kingdom of Jesus Christ; and to furthering the preaching of the gospel everywhere; to the end that God may be honoured and served by everyone, as he requires in his Word.

Kuyper's objections were several-fold:

- It was taken over by the Reformed fathers from Romanish practices

- It uses Constantinian language

- The sword should not be used to kill heretics

- It presupposes that the magistrate can judge the difference between truth and heresy.

Kuyper, however, recognised that in arguing against it he conflicted with the Reformers including Calvin.

A change was necessary, argued Kuyper, because of the development of pluralism in society. There were now many churches with different confessions - how could democratic governments decide which was the true church? Would different successive governments change their mind over which one was the true church? This was a different age to that when Guido de Bres (1522 - 1567) instigated the Belgic Confession. At issue, for Kuyper, was the relationship between church and state, and church and civil government.

P.J. Hoedemaker (1839-1910), who had been a colleague of Kuyper's at the Free University in Amsterdam, resigned his position when Kuyper led the Doleantie succession from the State church. Hoedemaker remained a member of the NHK, the State church.

He was in agreement with Kuyper on many issues but was in conflict with him on the question of church and state. For Hoedemaker, Kuyper's approach was an advocacy of the neutrality of the state and the split between church and state. He took issue with Kuyper over a number of points. He maintained that Kuyper was promoting the neutrality of the state.

In this book, we are only hearing one side of the debate. Kuyper responded to Hoedemaker but as yet that is untranslated; it appeared in a review in De Heraut (no. 1219, May 12th, 1901).

Kuyper's main arguments against Article 36 and his development of ideas in the relationship of church and state were published in Common Grace Volume 3. They were first written for De Heraut from October 1899 until November 1900. Alvarado has a useful appendix with the De Heraut issue numbers and the corresponding Common Grace chapters. Hoedemaker's book originally appeared in 1901 as a response to Kuyper's writings.

Hoedemaker took issue with Kuyper use of pragmatic reasons over and above scriptural reasons. He also disagreed with Kuyper's view of the church. Kuyper maintained that the invisible church existed from creation, but the church as institution began at Pentecost. This was a problem for Hoedemaker. 
Kuyper did not hold to a single state church institution. Hoedemaker did. For Kuyper the church was pluriform, there were different expressions of it. Kuyper rejected a one state one church position.

For Kuyper, the church arose from particular grace, the common grace. This meant for Kuyper the state could not judge between heresy and truth. It went beyond the calling and vocation of government. This was not a dualism between public and private, however. The state had no right to lord it over the church.

\subsection{Christian Faith, Philosophy and International Relations}

Although not dealing directly with Kuyper this volume has several authors writing from a Kuyperian perspective (these include Jim Skillen, Jonathan Chaplin and Lucas Friere). The book addresses the question: How can international issues be understood and addressed from a Christian faith perspective?

Three of the chapters discuss Kuyper directly, two of which have been previously published: van Overshot (2015) and Joustra (2018). The latter was discussed in Bishop (2019c). Also in this volume is a paper by Dennis P. Petri and Frans Veerman (2019) they propose a broad use of Kuyper's sphere sovereignty to use it as a measure for religious freedom (Petri \& Veerman, 2019: 241). They examine restrictions of sphere sovereignty in several countries including Libya, Egypt and Nigeria (where they examine to what extent Islamic extremism restricts sphere sovereignty), and Canada and Columbia (where they examine secular intolerance).

They conclude that:

We found the concept of sphere sovereignty to be a valuable analytical category to assess religious freedom in its full breadth and multidimensionality in a comparative perspective (Petri \& Veeman, 209: 260).

This volume serves to illustrate the contemporary relevance of Kuyper.

\section{JOURNAL ARTICLES}

Two articles by Bishop (2019a, 2019b) have dealt with two facets of Kuyper's thought: his approach to ethics and to art. The former appeared in this journal and uses the case study on vaccinations to examine how Kuyper treated an ethical issue. In the article on art (Bishop 2019a) Kuyper's views of art are examined. The paper suggests that:

[Kuyer's] contribution was timely and apposite, however, it was not always original as he developed ideas in Calvin, particularly in his Lectures. At times his view reveals hints of a residual dualism and neo-Platonism. These non-biblical notions are implicit in his view of beauty. Fortunately, other kuyperian scholars have identified some of these weaknesses and have been able to build on the strengths of Kuyper's position (Bishop, 2019b).

The views of Abraham Kuyper and Adolf Stöcker (1835-1909) towards Christian socialism and the Jewish question are compared in Kater (2019). Kater concludes:

Ultimately, both Christian-Social leaders perceived Jews from a theological perspective as 'enemies of Christ' and from a socio-political perspective as 'enemies of the "kleine luyden"'. It is only in the application of these ideas that the ways of Kuyper and Stöcker finally parted; whereas the latter opted for organized political antisemitism in order to maintain a Christian order in the German State, the former refrained from doing so, ultimately adhering to a pluralistic model of organizing society. While Stöcker saw Jews only as a threat, Kuyper was willing to accept their emancipation and objected to withdrawing once given rights 


\section{REVIEWS}

Falconer (2019) provides a detailed (16 pages) summary overview of Bartholomew's Contours of a Kuyperian Tradition (2017). His final evaluation of the book is worth quoting:

Bartholomew's book, Contours of the Kuyperian Tradition: A Systematic Theology, offers his readers a challenging, yet rich overview of a vast amount of theological output from Abraham Kuyper and Neo-Calvinism. Twelve well-chosen themes from the Kuyperian tradition were highlighted as chapters. As helpful as this is, though, one ought to keep in mind that the tradition consists of much more than these themes, and no doubt some readers would be surprised or even disappointed that other themes and issues of concern were not included in the book. Be that as it may, the book was well ordered and skilfully written. Bartholomew's evaluations at the end of most chapters were very applicable for our own time and context, especially those instances when he related the tradition to South African history and the current situation of the beloved country. For those wanting a big picture, a bird's-eye view by way of a working summary of Abraham Kuyper's thought, and the contributions from other Kuyperians, this is an invaluable resource (Falconer, 2019:211).

Mark Durie (2019) has an appreciative review of Kuyper's On Islam in Themelios, noting:

Kuyper's presentation of Islam is mainly sympathetic, although it is a "warts-andall" approach. He even hopes that Islam, which he in many respects admires, will unite with Christianity to defeat paganism (Durie, 2019:420).

\section{CONCLUSION}

The three volumes of the Kuyper Translation Project have marked another great year for Kuyper studies. The introduction by Wagenman has provided a great entry point for those interested in but daunted by the larger works. The essays on Kuyperian approaches to international relations, vaccinations, and art reveal how fecund Kuyper's work continues to be. As Kuyper has it:

In God's creation nothing is secondary, nothing is superfluous, nothing can be dispensed with (2019a:123).

\section{BIBLIOGRAPHY}

\subsection{Works reviewed}

Bishop, S. 2019a. Kuyper and vaccinations a case study in Kuyper's approach to an ethical issue. Koers - Bulletin for Christian Scholarship, 84(1). https://doi.org/10.19108/KOERS.84.1.2462.

Bishop, S. 2019b. Kuyper's nascent views on art. Journal for Christian Scholarship, 55 (3\&4). 107-129.

Durie, M. 2019. Review of On Islam. Themelios, 44(2):419-420.

Falconer, R. 2019. Review of Bartholomew Contours of the Kuyperian Tradition. Conspectus-The Journal of the South African Theological Seminary, 28 (September): 197-212.

Hoedemaker, P. 2019. Article 36 of the Belgic Confession Vindicated against Dr Abraham Kuyper. Ruben Alvarado (Translator). Pantocrator Press.

Joustra, R. 2017. Abraham Kuyper among the nations. Politics and Religion, 1-23. https://doi.org/10.1017/ \$1755048317000554. In Polinder, S. \& Buijs, G.J. (ed.) 2019. Christian Faith, Philosophy and International Relations: The Lamb and the Wolf. Leiden: Brill, 151-172.

Kater, L. 2019. Either Mammon or the Messiah? The Christian-Social tradition in the Netherlands and Germany on the Jewish Question, 1875-1914. Trajecta, Religion, Culture and Society in the Low Countries, 28 (1): 23-44. https://doi.org/10.5117/TRA2019.1.002.KATE. 
Kuyper, A. 2019a. Common Grace. God's Gift for a Fallen World. The Doctrinal Section. Volume 2. Abraham Kuyper Collected Works in Public Theology. Translated by Nelson D. Kloosterman and Ed M. van der Maas; edited by Jordan J. Ballor and J. Daryl Charles. Bellingham, WA: Lexham Press.

Kuyper, A. 2019b. Pro Rege: The Kingship of Christ in its Operation. Volume 3. Abraham Kuyper Collected Works in Public Theology. Translated by Albert J. Gootjes; edited by John Kok and Nelson D. Kloosterman. Bellingham, WA: Lexham Press.

Kuyper, A. 2019c. On Education. Abraham Kuyper Collected Works in Public Theology. Translated by Harry Van Dyke; edited by Wendy Naylor and Harry Van Dyke. Bellingham, WA: Lexham Press.

Petri, D.P. \& Veerman, F. 2019. Revisiting Sphere Sovereignty to Interpret Restrictions on Religious Freedom. In Christian Faith, Philosophy and International Relations. In Polinder, S, and Buijs, G.J. (ed.) 2019. Christian Faith, Philosophy and International Relations: The Lamb and the Wolf. Leiden: Brill. 240-262. https://doi.org/10.1163/9789004409897_015.

Polinder, S. \& Buijs, G.J. (ed.) 2019. Christian Faith, Philosophy \& International Relations: The Lamb and the Wolf. Leiden: Brill. https://doi.org/10.1163/9789004409897.

Van Oorschot, F. 2015. Common Grace as a Hermeneutical Approach to Globalization? Kuyper's Teaching of Common Grace in Current Public Theological Reflection on Globalization. Philosophia Reformata, 7898. In 93-113. Also in Polinder, S. \& Buijs, G.J. (ed.) 2019. Christian Faith, Philosophy and International Relations: The Lamb and the Wolf. Leiden: Brill. https://doi.org/10.1163/9789004409897_007.

Wagenman, M. 2019. Engaging the World with Abraham Kuyper. Bellingham, MA: Lexham Press.

\subsection{Other works mentioned}

Bartholomew, C.G. 2017. Contours of the Kuyperian Tradition: A Systematic Introduction. Downers' Grove: IVP Academic.

Bishop, S. 2019c. Kuyperania 2018. Koers - Bulletin for Christian Scholarship, 84(1). Available at: https:// doi.org/10.19108/KOERS.84.1.2450.

Brummel, N.C. 2018. Dutch Reformed Theologians: Explorations in Prominent Theologians and their Central ideas. CreateSpace Independent Publishing Platform (ISBN 978-1982037925).

Kuipers, T. 2011. Abraham Kuyper: An Annotated Bibliography 1857-2010. Leiden: Brill.

Min, J.K. 2009. Sin and Politics: Issues in Reformed Theology. New York: Peter Lang. 